\title{
PEREMPUAN HINDU DI ERA GLOBALISASI
}

Oleh :

Putu Sri Junianti

I Made Wirahadi Kusuma

\begin{abstract}
Hindu women are living beings who are creations from God or Ida Sang Hyang Widhi Wasa who have many roles in life. Especially women have the virtue of thinking so they are able to deal with all kinds of problems in their lives. With the problems in their lives, women often experience discrimination that befalls them both in their families and in society. Women have special rights that deserve respect, are protected and cherished not to be insulted or harassed. Along with the development of time there have been various forms of change in the globalization experienced mainly by women since long ago. The development of the world of technology and information makes women still considered weak creatures, so that women to maintain their position in the household emerged emancipation of women. In the past, women only had domestic duties in the household, now women can think creatively to have a career in the household without eliminating the domestic tasks that they have. As a result of the influence of globalization experienced by women, women have become more motivated so that they do not miss the times. Women want to be respected and respected so that there is no oppression in the family and women are often considered to be weak creatures even though there are actually strong creatures.
\end{abstract}

Keywords: Hindu women, change, the era of globalization

\section{PENDAHULUAN}

Tuhan telah menciptakan banyak makhluk hidup didunia ini seperti manusia, hewan dan tumbuh-tumbuhan. Tetapi manusia mendapatkan kedudukan tertinggi karena memiliki Tri Pramana yaitu bayu (kemampuan untuk bergerak), sabda (kemampuan untuk berbicara) dan idep (kemampuan berpikir). Manusia adalah makhluk dari ciptaan Tuhan atau Ida Sang Hyang Widhi Wasa dengan segala potensinya yang tunduk kepada aturan- aturan hukum alam, serta mengalami kelahiran, pertumbuhan, perkembangan dan kematian yang berkaitan atau berinteraksi dengan alam lingkungannya pada sebuah hubungan timbal balik baik kearah yang positif ataupun negatif. Di dunia ini Tuhan menciptakan manusia dengan dua jenis kelamin yaitu laki-laki dan perempuan. Perempuan pada era globalisasi saat ini menjadi sorotan karena adanya kata "Emansipasi Wanita" yang menjadi suatu kepercayaan diri yang 
dapat membangkitkan semangat kaum hawa (perempuan) di masyarakat. Emansipasi dalam arti luas mengandung arti kebebasan, yaitu usaha untuk membebaskan diri dari kekuatankekuatan alam atau kekuatan transendental kemudian dikendalikan atau dijinakkanlah kekuatan-kekuatan tersebut. Arti yang lebih luas lagi dari emansipasi yaitu penghapusan dari semua ikatan perbudakan, ketergantungan dan penindasan. Konsep dari emansipasi yaitu membebaskan diri dari ketidak adilan, ketidak mampuan, perbudakan, penindasan, ekspoitasi dan kesengsaraan hidup sehingga dapat diberikannya hak-hak manusiawi yang wajar.

Pada sistem kekeluargaan yang sedang berlaku dalam masyarakat di Indonesia sangatlah beragam. Salah satu contohnya di masyarakat Bali yang menekankan pada sistem patrilineal. Patrilineal merupakan sistem yang dilacak dari garis keturunan bapak atau istilahnya kapurusa atau purusa yang dimana laki-laki lebih memiliki peran utama dalam keluaraga dibandingkan dengan perempuan. Perempuan hanya memiliki tugas-tugas domestik (didalam rumah) seperti melahirkan, mengasuh dan mendidik anak, memasak, membersihkan dan merawat rumah yang merupakan kodrat perempuan (PKBI, 2015). Dengan adanya kemajuan di era globalisasi saat ini telah mengalami perkembangan ilmu pengetahuan dan kemajuan teknologi yang semakin meningkat. Serta adanya persaingan di dunia kerja yang semakin meningkat. Dengan persaingan yang semakin ketat ini timbulah persaingan antar gender yang tidak dapat dihindari. Pada laki-laki ataupun perempuan yang terus bersaing untuk mendapatkan suatu pekerjaan. Umumnya perempuan hanya memiliki tugas didalam rumah tangga tetapi sekarang perempuan juga dituntut untuk menghasilkan uang bagi ekonomi keluarganya.

Perempuan akan berubah untuk mengikuti perkembangan jaman yang terjadi secara global. Dengan mudah perempuan dapat mengakses informasi serta dapat dengan mudah untuk menyerap informasi yang menyebabkan perempuan ingin menunjukkan keberadaannya sesuai dengan kebebasan yang ingin dicapai. Dalam kehidupan modern perempuan juga memiliki hak yang sama seperti laki-laki dan perempuan juga dapat bekerja sebagai angkatan bersenjata, pengusaha bahkan sebagai presiden seperti Megawati Soekarno Putri yang merupakan Presiden RI ke-4. Namun ada pada sebagian masyarakat yang menganggap bahwa perempuan yang ikut bersaing di dunia kerja merupakan hal yang lazim dan sebagian masyarakat lainnya berpendapat hal ini merupakan sesuatu yang tidak lazim. Beberapa pihak dari masyarakat berpikir bahwa perempuan tidak pantas untuk bersaing di dunia kerja yang cukup keras, dikarenakan perempuan adalah makhluk yang lemah. Hal inilah yang menimbulkan diskriminasi perempuan di dalam dunia pekerjaan. Diskriminasi yang terjadi terhadap perempuan masih sangat terlihat dalam dunia kerja. Banyak sekali wanita yang tidak bisa untuk mendapatkan hak dalam pekerjaan. Contohnya dapat dilihat dalam suatu struktur perusahaan, jarang sekali orang melihat bahwa perempuan yang menjabat sebagai pemimpin. Dan selain itu di dalam penerimaan pekerja perempuan yang sedang melamar pekerjaan pada perusahaan memiliki syarat-syarat tertentu, seperti berpenampilan menarik, belum menikah, belum memiliki anak, harus tinggal di 
asrama dan lain sebagainya. Serta gaji mereka pun kadang-kadang berbeda dengan pekerja laki-laki.

Dari hal yang telah terjadi pada ketidakadilan yang dialami perempuan tersebut maka secara khusus di Indonesia telah menugaskan satu departemen yang dapat menampung aspirasi ataupun keluhankeluhan serta memberikan penguatan kepada perempuan yang ada di Indonesia agar dapat terbebas dari ketidakadilan yakni Kementerian Negara Pemberdayaan Perempuan sesuai dengan pasal 27 UUD 1945 yang diperkuat melalui ratifikasi konversi penghapusan segala bentuk diskriminasi terhadap perempuan (Convention on The Elimination of All Form of Diskrimination Against Women/ CEDAW) ke dalam UU No, 7 Tahun 1984 serta Landasan Aksi dan Deklarasi Beijing hasil konferensi dunia tentang perempuan keempat di Beijing pada tahun 1995 (Bantas dkk, 2004 : 2). Adanya bentuk dari ketidak adilan dalam pembakuan peran gender di Masyarakat dibagi menjadi lima yaitu : 1) Marjinalisasi (Pemiskinan Ekonomi), 2) Subordinasi perempuan, 3) Pelabelan atau penadaan (Stereotip) perempuan, 4) Kekerasan fisik dan mental psikologis perempuan, 5) Beban kerja ganda perempuan (Bantas dkk, 2004 : 18-21).

\section{PEMBAHASAN}

\subsection{Perempuan Hindu}

Kata "wanita" berasal dari bahasa Sansekerta yaitu "Vanita" yang berakar dari kata "van" yang berarti beloved = yang dicintai, wife $=$ istri, girl=anakgadis, dan woman=perempuan .
Dari kata "Van" kemudian mendapatkan akhiran "hita" lalu menjadi "vanita" yang berarti sejahtera, baik, dan mulia. Istilah lain dari wanita yaitu perempuan. Menurut Prof. M. Yamin, perempuan berasal dari kata "pu" atau "empu" dan mendapat awalan "pe" dan akhiran "an" sehingga menjadi "perempuan" yang memiliki arti mereka yang dicintai baik, dimuliakan, dan membaa kesejahteraan, dihormati dan diutamakan (Weti, 2001 : 25). Kata "empu" adalah istilah untuk gelar yang diberikan kepada mereka yang patut untuk dihormati, dimuliakan dan juga orang-orang suci Hindu. Kata "empu" dihubungkan dengan "wanita atau perempuan" dalam tugasnya dapat diartikan sebagai pengasuh. Kenyataannya di masyarakat bahwa perempuan mempunyai tugas untuk mengasuh anak-anak, suami dan keluarganya. Perempuan memiliki keutamaan itu karena disebabkan pada manusia yang diberikan kekuatan yang lebih berupa idep (kemampuan dalam bepikir) sehingga manusia mampu berpikir untuk dapat menghadapi berbagai macam atau jenis permasalahan dalam hidupnya. Keutamaan tersebut dalam pustaka suci Sarasamuccaya Bab I, sloka II dinyatakan sebagai berikut.

Risakwehning sarwa bhuta, iking janma wwang juga wenang gumawayaken ikang subhasubhakarma, kunang panentasakena ring subhakarma juga ikang asubhakarma, pjalaning dadi wwang.

\section{Terjemahan :}

Diantara makhluk hidup, hanya yang dilahirkan jadi manusia sajalah yang dapat melaksanakan perbuatan baik atau buruk leburlah ke dalam perbuatan baik segala 
perbuatan buruk itu. Demikianlah gunanya (phalanya) menjadi manusia

Berdasarkan pada keutamaannya, pengertian perempuan atau wanita yang dihubungkan dengan perannya dalam kehidupan sehari-hari yang dilakukan oleh seorang perempuan pada umumnya. Perempuan adalah kaum yang dibebani dengan tanggung jawab moral untuk dapat mengurus, merawat dan mendidik umat manusia. Serta perempuan diibaratkan dengan dewi kekayaan yang membawa kegembiraan dan keberuntungan bagi rumah tangganya. Dengan adanya hal tersebut maka perempuan adalah makhluk ciptaan Tuhan yang perkasa yang tidak bisa disamai dengan laki-laki. Dan berdasarkan penjelasan tersebut maka dapat disimpulkan bahwa perempuan Hindu adalah makhluk ciptaan Tuhan yang perkasa yang memiliki tugas untuk mengasuh anak, suami dan keluarganya yang menganut agama Hindu dengan mengamalka ajaran Dharma (kebaikan).

\subsection{Perempuan dalam Sastra Hindu}

Agama Hindu mempersonifikasikan Tuhan dengan simbol wujud perempuan seperti Dewi Saraswati, Dewi Durga, Dewi Laksmi, Dewi Savitri, Dewi Kali dan dewi lainnya. Simbol ini dipergunakan karena memandang bahwa perempuan itu merupakan sesuatu keberadaan yang suci sebagai Sakti yaitu unsur feminism dari Brahma atau kekuatan dari Brahman yang memiliki peran dalam mensejahterakan dan mengharmoniskan alam semesta. Dari pemahaman ini, sesungguhnya Veda memandang bahwa perempuan adalah sosok yang penting dalam kehidupan yang patut dihormati. Kedudukan laki-laki dengan perempuan dalam Hindu diakui sama karena itu perempuan harus dihormati dan disayangi oleh ayah, kakak, suami dan iparnya (Manawa Dharmasastra III : 55) dan dalam sloka selanjutnya berbunyi bahwa "Orang yang ingin hidup bahagia harus selalu menghormati perempuan dan hari raya memberikan hadiah perhiasan, pakaian dan makanan" (Manawa Dharmasastra III : 59). Dan pada Kitab Atharva Veda V.17.3.4 menyatakan bahwa : "Dimana kehormatan perempuan dilindungi, bangsa itu akan selamat dan terjamin dan seseorang perempuan yang tidak dihormati dapat meruntuhkan bangsa itu" (Maswinara, 1999).

Dari cerita Itihasa (Ramayana) merupakan saksi jatuhnya bangsa-bangsa besar yang diakibatkan oleh adanya penghinaan terhadap kaum perempuan. Rahwana dengan kerjaannya Alengka luluh lantak akibat dari penghinaan yang dilakukannya dalam penculikan Dewi Sita, kemudian dalam kitab Mahabharata bangsa Kuru terjadi perang antar saudara yaitu antara Kuraa dan Pandawa karena penghinaan dan pelecehan terhadap kaum perempuan yaitu tragedi penelanjangan Dewi Drupadi yang dijadikan sebagai bahan taruhan judi oleh Dursasana (Pandit terjemahan Paramitha, 2006 : 72). Tokoh perempuan dimasa lalu yang telah ditemukan dalam Upanisad dan sastra-sastra Hindu disebutkan dalam kitab Veda ditemukannya perempuan yang sangat dihormati sebagai para Brahmavadini seperti : Visvavara, Apala, Ghosa, Godha yang merupakan istri dari Vasukra dan saudara perempuan dari Maharsi Agastya, Lopamudra, Sasvati dan Romasa. Serta tokoh lainnya dalam 
Ramayana seperti : Anasuya (jnanin) yang memberikan nasehat kepada Rama, Sita dan Laksmana, Sabari Svayampraba (pertapa yang telah menolong Hanoman), Trijata, Madodari, Sita, dan Kausalya. Dalam Mahabharata antara lain yaitu : Drupadi, Kunti, Sakuntala dan dalam Purana ada Devahuti ibu dari Maharsi Kapila (Titib, 1998 : 27-28). Dewi Saraswati, Durga dan Laksmi adalah aspek perempuan lainnya yang sering dijadikan sebagai perayaan hari raya umat Hindu baik memperingati hari pesta keagamaan (Gayatri Japa, Durga Puja) dan hari kelahiran tokoh suci serta hari untuk melaksanakan brata (Ekadasi, Laksmi Vrata).

Di Indonesia dikenal dengan tokoh suci perempuannya, khusus dalam KerajaanJawa, seperti kisah Pramodhawardhani yang menikah dengan Pancapana yang dibuktikan dengan peninggalannya berupa Candi Kalasan dan Candi Sewu. Raja ke-3 dari kerajaan Majapahit yaitu dipimpin oleh seorang perempuan bernama Tribhuanatunggadewi yang dapat menjalankan pemerintahnya dengan baik kemudian dibantu oleh patih Gajah Mada yang merupakan patih yg perkasa dan selalu berjaya. Kemudian Tribhuanatunggadewi menikah dengan Raja Cakrada dan melahirkan anak yang bernama Hayam Wuruk, saat inilah pemerintahan dari raja Hayam Wuruk mencapai puncak kejayaannya dan kerajaan Majapahit menyatukan Nusantara dengan sumpahnya yaitu Amukti Palapa (Badrika, 2006 : 55). Perempuan dalam sastra-sastra India maupun Jawa Kuno memiliki peran yang penting dalam keikutsertaannya untuk membangun kesejahteraan dan kedamaian dalam kehidupan ini untuk menjadi lebih baik.

\subsection{Perempuan Hindu dalam Kitab Sarasamuccaya}

Hindu adalah agama kebenaran yang abadi (Sanatana Dharma) yang didalam ajarannya bersumber pada Veda. Pada kitab Veda sesungguhnya sangatlah menghormati dan menghargai perempuan. Maka terlebih dahulu membahas tentang perempuan dalam pustaka seperti : Bhagavadgita, Manawa Dharmasastra, Atharva Veda dan Yajur Veda. Pada Kitab Bhagavadgita IX. 17 menjelaskan bahwa Aku adalah Bapa, Ibu, pelindung dari alam semesta ini. Dalam kitab Manawa Dharmasastra III : 56 menjelaskan bahwa ketika wanita tidak dihormati, maka segala yadnya tidak berpahala. Kemudian pada Atharva Veda V. 17. 3. 4 menerangkan bahwa jika perempuan dihormati maka Negara akan sejahtera. Dan selanjutnya dijelaskan dalam Yajur Veda 39 menerangkan bahwa meletakan lagi diatas tempat dudukmu, air agni dan bumi. Padanya engkau menakjubkan berbaring seperti diatas pangkuan seorang ibu (Griffith, 2006 : 216). Dalam Kama Sutra dan Brhadaranyaka Upanisad yang menempatkan perempuan pada singgasana atau posisi yang mulia, karena pada Kama Sutra karya Rsi Vatsyayana menerangkan bahwa peranan perempuan sangatlah vital dalam hubungan seksualitas dan penerus keturunan (Suwantana 2007 : 34). Dan pada Brhadaranyaka Upanisad VI. 2. 13 menyatakan bahwa pada hubungan suami istri, alat kelamin perempuan mempunyai kewajiban untuk mengandung anaknya dengan lakilaki yang mulia agar mendapatkan anak yang suputra.

Kitab suci agama Hindu sangatlah menjunjung tinggi harkat dan martabat 
perempuan, akan tetapi karena adanya pembahasan yang dikhususkan untuk halhal tertentu seperti untuk pemimpin, pandita, atau seseorang yang telah memasuki tahapan Wanaprasta danSanyasin. Pada pembahasannya tentang sloka 424-442 berkaitan dengan perempuan yang seolah-olah bertolak belakang dengan keseluruhan kitab Hindu tersebut yang sebenarnya selalu menghormati perempuan. Bhagawan Waisampayana menyapaikan ini karena memiliki tujuan agar selalu berpegangan teguh pada Dharma, sehingga dijauhi oleh malapataka yang akan dialami oleh leluhurnya tidak terulang kembali. Yaitu pada perang antar saudara yang dialami oleh pasukan Kurawa dan Pandawa yang disebabkan oleh penghinaan dan pelecehan yang dialami oleh Dewi Drupadi yang dijadikan barang taruhan oleh Dursasana. Oleh karena penghinaan tersebut makapihak Kurawa sudah keterlaluan dan upaya untuk berdamai pun tidak disepakati, dan akhirnya meletuslah perang dasyat tersebut. Salah satu isi dari kitab Sarasamuccaya sloka 424 yaitu :

Na stribhyah kincidanyadvai papiyo bhuvi vidyate,

Striyo mulamanarthanam manasapi ca cintitah.

\section{Terjemahan :}

Diantara sekian banyak yang dirindukan, tidak ada yang menyamai wanita dalam hal membuat kesengsaraan; apalagi memperolehnya dengan cara jahat; karenanya singkirkanlah wanita itu, meskipun hanya di angan-angan, hendaklah ditinggalkan saja.

Pada bagian kitab Sarasamuccaya yang diuraikan tentang perempuan (Stri) yaitu dari sloka 424 sampai dnegan 442 (Kajeng, 1999 : 331-344) menjelaskan tentang perempuan dipandang sebagai pembawa sial atau kesengsaraan dan harus dijauhkan terutama dari golongan Pandhita (sloka 434-435). Isi dari kitab Sarasamuccaya sloka 434 yaitu :

Stri nama maya nikrtih krodhamatsaryavigraha,

Dtura tyajedanaryam tamjvalitamedhayavadbudhah.

\section{Terjemahan :}

Sesungguhnya wanita itu tidak lain dari pada sulap, berbahaya, berwujud kemarahan, cemburu; oleh karen itu maka dijatuhkan oleh sang pandita, sebab tiada bedanya dengan sesuatu yang tidak suci (untuk digunakan kurban kebaktian), sesuatu yang menjijikan, sesuatu yang kotor.

Dan pada kitab Sarasamuccaya sloka 435 berisi tentang,

Svabhavaccaiva narinam naranamika dusanam,

Itthvam vain a pramadyanti pramadasu vipascitah.

\section{Terjemahan :}

Kebiasaan wanitalah yang berbuat bencana kepada orang; dukacita dan prihatin ditimbulkan olehnya, serta membatalkan segala kerja; sadarlah sang pandita akan hal itu; karenanya, selalu berusaha menjauhi wanita.

Padahal pada kitab Sarasamuccaya ini merupakan kitab suci Veda yang harus dapat 
dipahami oleh umat Hindu khususnya, tetapi karena adanya pemahaman yang keliru tentang sloka ini makan kedudukan perempuan dalam Sarasamuccaya itu seolah-oleh direndahkan dan dijauhkan. Intinya dari permasalahan ini ada pada pengedalian diri dari seorang laki-laki terhap objeknya yaitu perempuan, janganlah berpikiran negatif tentang perempuan.

\subsection{Peranan Perempuan dalam Kehidupan}

\subsubsection{Peran Perempuan sebagai Ibu}

Kehidupan berumah tangga ialah bagian dari masyarakat terkecil yang merupakan tempat yang baik untuk menanamkan segala bentuk kebajikan. Didalam rumah tangga terdapat anggota keluarga inti yang terdiri dari ayah, ibu dan anak. Ayah memiliki peran sebagai kepala rumah tangga, ibu sebagai ibu rumah tangga serta anak memiliki kewajiban untuk mendapatkan kasih sayang dari keluarganya. Seorang ibu memiliki dua fungsi dari rumah tangga yaitu sebagai seorang istri dan seorang ibu, kedua fungsi ini merupakan tugas yang harus dilaksanakan secara seimbang. Seorang istri harus berusaha untuk selalu terlihat cantik, bersih, ramah dan bergairah dihadapan suami dan seorang istri juga harus memelihara kesatuan yang harmonis dalam keluarga dikarenakan seorang istri yang didambakan oleh suami yaitu istri yang penuh kesetiaan dan pengabdian serta saling menghormati dan penuh pengertian dalam situasi, kondisi yang sedang dialami pada suami (Suhardi, 2015 : 25). Di dalam Manawa Dharmasastra V. 158 menerangkan bahwa "perempuan senantiasa diharapkan selalu merasa bahagia dan setia kepada sang suaminya dalam segala hal".
Suami dan istri mempunyai fungsi yang berbeda, tetapi dihadapan Tuhan adalah sama. Oleh karena itu, sepasang suami istri yang seagama merupakan awal dari untuk menjalankan kehidupan grhasta dengan baik. Cara yang dapat dipergunakan yaitu dengan menjalin komunikasi yang baik antar suami dan istri yang sah walaupun keduanya sangat sibuk, namun harus ada pengaturan pada waktu berkomunikasiagartidak menganggu pekerjaan. Dengan saling memberikan pengertian antara suami dan istri maka kehidupan berumah tangga akan terjalin harmonis. Dalam naskah Dr. Murbiah Fruhan mengatakan bahwa : "Penghasilan seorang suami akan bertambah $30 \%$ sampai $60 \%$ karena beresnya pekerjaan istri dalam rumah tangga" (Wiratmaja 1991 : 39). Seorang istri harus mengarahkan suaminya agar berpedoman pada kebenaran (dharma) serta bertanggung jawab terhadap keluarganya agar mencapai kebahagiaan baik secara sekala (nyata) dan niskala (tidak nyata). Istri juga merupakan seorang ibu yang mengasuh dan mendidik anaknya kemudian mengajari anak tersebut dengan budi pekerti yang luhur dan moral yang tinggi. Karena pendidikan yang harmonis adalah pendidikan yang meliputi kecerdasan akal dan pikiran serta mental spiritual. Pendidikan ini dapat dimulai ketika bayi masih dalam kandungan ibunya (pendidikan prenatal). Oleh karena itu seorang ibu pada saat itu harus berhati-hati dalam pikiran, ucapan dan tindakan. Jadi seorang anak harus menghormati jasa orang tua mereka, karena merekalah yang selalu membimbing serta mengarahkan dan memberikan motivasi dalam kehidupan. Ibu adalah seorang perempuan yang memiliki hati lembut dan memberikan kasih sayang kepada anaknya serta mengerti 
tentang perasaan anaknya, ayah adalah seorang yang selalu melindungi anaknya dari bahaya luar ataupun dalam.

\subsubsection{Peran Perempuan sebagai Pelaksana Agama}

Kitab Manawa Dharmasastra menjelaskan bahwa upacara keagamaan merupakan kebahagiaan dari rumah tangga, dan surga leluhur yang didukung oleh istri. Istri memiliki peran sebagai seorang ibu dan sebagai pelaksana keagamaan (yadnya) yang meliputi pelaksanaan dari Panca Yadnya terdiri dari Dewa Yadnya, Pitra Yadnya, Rsi Yadnya, Manusa Yadnya dan Bhuta Yadnya (Tim Penyusun, 2007 : 35). Didalam hal ini lakilaki tidak boleh hanya berpangku tangan ke perempuan, tetapi harus bersama-sama untuk melaksanakan kegiatan keagamaan dengan rasa kebersamaan. Pelaksanaan yadnya merupakan kewajiban dari suami istri yang memiliki tujuan untuk kebahagiaan secara sekala dan niskala, serta dijelaskan dalam Manawa Dharmasastra IX.96 menyatakan :

\section{Praajnartham striyah srstah \\ Samtanathamca manawah \\ Tasmat sadharani dharmah \\ Crutau patnya sahaditah.}

\section{Terjemahan :}

Untuk menjadi ibu, wanita itu diciptakan dan untuk menjadi ayah, laki-laki itu diciptakan upacara keagamaan karena itu, ditetapkan didalam Veda untuk dilakukan oleh suami bersama istrinya.

Dari sloka tersebut maka seorang perempua harus berperan aktif didalam pelaksanaan gam dan wajib untuk mengenal dasar-dasar agama atau Tri Kerangka Agama (tattwa, susila, upacara) sehingga pada tujuan hidup ini yaitu Catur Purusa Artha (dharma, artha, kama, dan moksa) akan tercapai dengan dilandasi pelaksanaan yang sesuai dengan bhakti, karma, jnana dan yoga. Perempuan memiliki hak yang sama dengan laki-laki untuk dapat mencapai kehidupan spiritual dan tujuan terakhir yaitu moksa (pembebasan). Untuk mencapai tatatan kehidupan spiritual ini maka tidak ada tembok pemisah antara kaum laki-laki dengan kaum perempuan, karena pada dasarnya setiap manusia di dunia ini mempunyai hak yang sama untuk mencapi pendakian spiritual.

\subsubsection{Peran Perempuan dalam Kehidupan Bermasyarakat}

Manusiayang merupakanmakhlukindividu dan makhluk sosial karena selalu berinteraksi dengan satu sama lain untuk memudahkannya dalam pencapaian pemenuhan kebutuhan dalam kehidupan ini. Oleh karena itu dalam hubungn dimasyarakat harus memiliki sifat yang santun untuk menjauhi diri dari amarah, iri dan dengki. Dikehidupan masyarakat perempuan merupakan tiang Negara karena tugas utamanya yaitu sebagai pendidik anak-anaknya. Sehingga apabila seorang ibu melalaikan tugasnya maka nasib bangsa dan Negara dimasa depan akan terbengkalai (Wiratmadja, 1999 : 11 ). Untuk menjaalankan kehidupan ini, baik dalam masyarakat, berbangsa dan bernegara perempuan mempunyai andil besar dalam mendukung pelaksanaan dalam pembangunan. Sehingga pada kehidupan nyata ini peranan perempuan sangat berpengaruh untuk mencapai tatanan kehidupan yang lebih 
baik lagi dari sebelumnya. Dalam kehidupan bangsa Indonesia untuk mewujudkan cita-cita yang telah tertuang dalam pancasila, sila yang ke5 yaitu keadilan sosial bagi seluruh rakyat Indonesia. Pada sila tersebut mengandung arti kehidupan yang makmur dan merata secara lahir dan batin untuk membangun manusia seutuhnya (Kaelan, $2002: 43$ ).

Bangsa yang maju adalah bangsa yang perlu mengakui harus adanya perbaikan kualitas, status, serta peran perempuan dalam pembangunan untuk meninggkatkan keadilan sosial serta memenuhi hak-hak asasi manusai yang setara antara kaum laki-laki dan kaum perempuan. Pada peningkatan kualitas, perempuan menjadi dasar untuk menciptakan suatu pembangunan yang berkelanjutan bagi sebuah bangsa. Dengan demikian dalam upaya untuk peningkatan kualitas bagi kaum perempuan maka dilakukannya dalam rangka untuk menciptakan keserasian antara keadilan sosial dan hak-hak asasi bagi perempuan dan laki-laki serta alasan efesiensi ekonomi dalam membentuk pembangunan yang berkelanjutan.

\subsection{Perubahan pada Perempuan Hindu Menjadi Perempuan Karier}

Karier merupakan suatu keahlian yang dapat diamalkan di lingkungan masyarakat dan dapat dijadikan sebagai sumber kehidupan didalam keluarga. Umumnya karier memiliki tujuan untuk mendapatkan sejumlah uang yang dapat mendukung ekonomi diri atau keluarga. Banyak kaum perempuan tidak menyadari bahwa apa yang dilakukannya itu bisa dianggap sebagai karier sepanjang yang dia mau serta berusaha untuk meningkatkan kemampuan yang dimilikinya. Perempuan dapat mempergunakan kemampuan tersebut untuk mendapatkan sesuatu yang berupa uang atau yang setara dengan nilai uang. Janganlah pernah menilai uang dari berapa sudut yang dihasilnya, tetapi lihatlah berapa hasil yang dapat diperoleh kalau disejajarkan dengan penghasilan uang yang dihasilkan dari pekerjaan tersebu. Dalam pekerjaan ibu rumah tangga dapat dijadikan sebagai sebuah karier, bukan hanya sebagai tugas pada kegiatan sehari-hari. Untuk mengelola rumah tangga harus membekali diri dengan pengetahuan yang luas, seperti kepemimpinan, psikologi perkembangan, pengetahuan tentang masakan, komunikasi personal dan interpersonal, pemahaman tentang hubungan suami, istri dan anak, serta harus bisa mengatur keuangan keluarga, dan pengetahuan lainnya (Suryani, 2003 : 74-75).

Terkadang ada seseorang yang memiliki pendapatbahwakeberhasilamseseorangdidalam mengembangkan kariernya sangat ditentukan oleh adanya kesempata. Kesempatan itu ada banyak namun tidak mau untuk dipergunakan. Sehingga kadang-kadang banyak orang merasa kalau didunia ini tidak ada kesempatan, padahal sesungguhnya banyak ada kesempatan kalau seseorang mau untuk mencarinya. Sekarang tergantung pada orang tersebut jika bisa memanfaatkan kesempatan yang ada secara profesional maka hasil yang akan dicapainya pun akan maksimal. Pada kesempatan untuk menggabungkan kemampuan yang diperoleh dalam pendidikan di sekolah dan pada naluri yang ingin belajar maka seseorang bisa bekerja secara profesional. Jika ada kesempatan yang baik maka kemampuan yang telah dimiliki 
seseorang pun dapat memiliki hubungan dengan orang lain yang membutuhkan bantuan serta dapat dikembangkan dan dimanfaatkan untuk kepentingan lingkungan sekitar.

Setiap pekerjaaan yang telah menghasilkan suatu kemampuan untuk mengembangkan karier. Pendidikan formal hanya memberikan kemampuan daya nalar manusia untuk dapat memahami apa yang diperlukan oleh manusia itu. Tetapi pada pendidikan informal yang ada di rumah tangga ataupu masyarakat sekitar sangat membantu untuk membuat pola pikir seseorang menjadi lebih kreatif. Pada ilmu yang telah diperoleh didalam sekolah kemudian dapat dipraktekan dilingkungan masyarakat serta dimanfaatkan agar memperoleh sesuatu baik berpa uang, kedudukan ataupun suatu penghargaan tergantung dari keinginan orang tersebut. Pelajaran yang telah diperoleh dalam sekolah tidak menjamin seseorang untuk mendapatkan pekerjaan, tetapi dengan memberikan pemikiran atau daya nalar dalam pikiran manusia untuk dapat menciptakan pekerjaan, mencari pekerjaan. Jenjang berikurnya dalam karier yaitu seorang perempuan harus kreatif untuk dapat menciptakan hal-hal yang baru yang tidak ia miliki sejak kecil. Sekarang tergantung dari bagaimana perempuan tersebut memperoleh suatu pengalaman. Kalau orang tuanya telah memberikan kesempatan pada perempuan untuk belajar dari pengalaman maka timbullah banyak masalah yang akan dihadapinya kemudian banyak hal yang dapat ditangani secara cepat sehingga membantunya untuk menjadi orang yang berpikiran kreatif. Sekarang pekerjaan rumah tangga memang kelihatannya sangat sederhana, tetapi dari sanalah kemampuan perempuan bisa dilatih. Tergantung dari ia dapat mengatur waktu agar tetap bisa belajar namun ada juga waktu yang mengatur dalam membersihkan rumah, memasak dan apabila ada tamu yang datang ia dapat masuk kedalam pergaulannya (tetapi perlu diingat untuk memilah antara pergaulan yang positif yang negatif).

Cara untuk memberikan pemahaman kepada anak-anak dan remaja perempuan perlu ditanamkan sejak dini. Namun penanamannya harus sesuai dengan pertumbuhan umur anak, misalnya pada anak TK (Taman Kanak-kanak) : "Ada seorang pembantu, kemudian pembantu tersebut sangat diperlukan, dengan membantu seseorang orang bisa mendapatkan uang, makan serta tempat tinggal”. Maka anak-anak sejak Tk sudah diberikan pandangan bahwa apapun pekerjaan yang telah mereka lakukan atau dilaksanakan, mereka akan menjadi orang yang hebat karena bisa membantu orang lain dan dapat menghasilkan sebuah kedudukan dan uang sesuai dengan tingkatan pekerjaan yang ingin mereka geluti seperti menjadi seorang dokter, perawat polisi, ataupun pembantu rumah tangga.

\section{PENUTUP}

Perempuan adalah kaum yang dibebani dengan tanggung jawab moral untuk dapat mengurus, merawat dan mendidik umat manusia. Serta perempuan diibaratkan dengan dewi kekayaan yang membawa kegembiraan dan serta membawa keberuntungan bagi rumah tangganya. Maka perempuan merupakan makhluk ciptaan Tuhan yang perkasa yang tidak bisa disamai dengan laki-laki. Manakala 
seorang perempuan menjadi seorang ibu maka ia memiliki dua fungsi dari rumah tangga yaitu sebagai seorang istri dan seorang ibu, kedua fungsi ini merupakan tugas yang harus dilaksanakan secara seimbang. Seorang istri harus berusaha untuk selalu terlihat cantik, bersih, ramah dan bergairah dihadapan suami dan seorang istri juga harus memelihara kesatuan yang harmonis dalam keluarga dikarenakan seorang istri yang didambakan oleh suami yaitu istri yang penuh kesetiaan dan pengabdian serta saling menghormati dan penuh pengertian dalam situasi, kondisi yang sedang dialami pada suami. Perempuan memiliki peran sebagai istri sebagai pelaksana keagamaan (yadnya) yang meliputi pelaksanaan dari Panca Yadnya terdiri dari Dewa Yadnya, Pitra Yadnya, Rsi Yadnya, Manusa Yadnya dan Bhuta Yadnya. Dikehidupan masyarakat perempuan juga merupakan tiang Negara karena tugas utamanya yaitu sebagai pendidik anak-anaknya. Sehingga apabila seorang ibu melalaikan tugasnya maka nasib bangsa dan Negara dimasa depan akan terbengkalai. Serta perempuan Bali berperan aktif dalam pembangunan yang sejajar dengan kaum laki-laki. Maka dari itu perempuan Bali harus tetap untuk mengikuti dan meningkatkan kemampuannya melalui pendidikan informal ataupun formal. Pada aktivitas ini, perempuan Bali tidak hanya membangkitkan kesejahteraan keluarganya.

\section{DAFTAR PUSTAKA}

Adia, G.k, Wiratmadja. 1991. Perempuan Hindu dalam Suatu Proyeksi. Bandung : Ganesa Exact Bandung.
Arivia, Gadis. 2006. Pengurusutamaan Gender. Jakarta : Yayasan Jurnal perempun.

Bantas, Ketut Dkk. 2004. Gender Dalam Perspektif Hindu I. Jakarta : Kementrian pemberdayaan perempuan.

Fakih, Mansour. 2009. Runtuhnya Teori Pembanguna dan Globalisasi. Yogyakarta: Insist Press.

Griffith, R.T.H. 2006. Yajur Veda Samhita (Sukla Yajur Veda). Surabaya : Paramitha.

Kaelan. 2002. Filsafat Pancasila Pandangan Hidup Bangsa Indonesia. Yogyakarta : Paradigma.

Kajeng, I Nyoman dkk 1999. Sarasamuccaya Teks Sansekerta dan Jawa Kuno. Surabaya : Paramitha.

Maswinara, I Wayan. 1997. Kamasutra Dari Watsayana cet I. Surabaya : Paramitha.

Pandit, Bansi. 2006. Pemikiran Hindu (Pokokpokok Pikiran Agama Hindu dan Filsafat) terjemahan IGA Dewi Paramitha. Surabaya : Paramitha

Pudja G, Tjokorda Rai Sudharta. 2002. Veda Smrti Compedium Hukum Hindu. Jakarta : CV Felita Nursatama Lestari.

2005.

Bhagawad Gita (Pancamo Veda). Surabaya : Paramitha.

Sugiarto, R. 1980. Brhadaranyaka Upanisad cet III. Jakarta : Proyek pengadaan Kitab Suci Hindu.

Suhardi, Untung. 2015. Kedudukan Perempuan Hindudalam Kitab Sarasamuccaya (Kajian Etika Hindu). Surabaya : Paramitha. 
Suryani, Luh Ketut, 2003. Perempuan Bali Kini. Denpasar : PT. Offset BP Denpasar.

Suwantana, Gede. 2007. Seks Sebagai Pendakian Spiritual (Kajian Teks Rsi Sebina) cet I [ed] I Ketut Windya. Denpasar : Program Pascasarjana IHDN Kerjasmaa Dengan Sri Kahyangan.

Tim Penyusun, 2007. Kamus Besar Bahasa Indonesia Edisi III. Jakarta : Balai Pustaka.

Titib, I Made. 1998. Citra Perempuan Dalam Kakawin Ramayana (Cerminan Masyarakat Hindu Tentang Wanita). Surabaya : Paramitha

Weti, Ni Wayan. 2001. Kedudukan Ibu Dalam Keluarga di Desa Tampak Siring Kecamatan Tampak Siring. Denpasar : IHDN Denpasar. 